\title{
Effects of THAM Nasal Alkalinization on Airway Microbial Communities: A Pilot Study
}

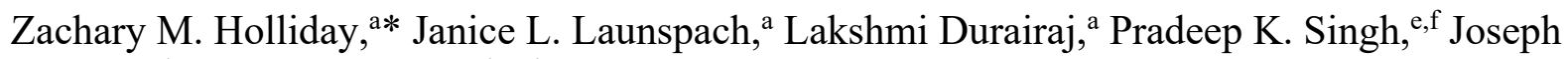
Zabner, ${ }^{\text {a,d }}$ \# David A. Stoltz ${ }^{\mathrm{a}, \mathrm{b}, \mathrm{c}, \mathrm{d}}$ \#

aDepartment of Internal Medicine, University of Iowa, Roy J. and Lucille A. Carver College of Medicine, Iowa City, IA, USA

bepartment of Biomedical Engineering, University of Iowa, Iowa City, IA, USA

'Department of Molecular Physiology and Biophysics, University of Iowa, Roy J. and Lucille A. Carver College of Medicine, Iowa City, IA, USA

dPappajohn Biomedical Institute, University of Iowa, Iowa City, IA, USA

e Department of Microbiology, University of Washington, Seattle, WA, USA

fDepartment of Medicine, University of Washington, Seattle, WA, USA

Running head: Alkalinization Alters the Nasal Microbial Profile

\section{\#Corresponding Authors:}

University of Iowa

169 Newton Rd, 6334 PBDB

Iowa City, IA 52242

Phone: 319-384-1107

Fax: 319-353-6406

E-mail: david-stoltz@uiowa.edu and joseph-zabner@uiowa.edu

*Present address: Zachary Holliday, Department of Medicine, University of Missouri School of Medicine, Columbia, MO, USA 


\section{ABSTRACT}

Objectives: In cystic fibrosis (CF), loss of CFTR-mediated bicarbonate secretion reduces the airway surface liquid (ASL) pH causing airway host defense defects. Aerosolized sodium bicarbonate can reverse these defects, but its effects are short-lived. Aerosolized tromethamine (THAM) also raises the ASL $\mathrm{pH}$ but its effects are much longer lasting. In this pilot study, we tested the hypothesis that nasally administered THAM would alter the nasal bacterial composition in adults with and without CF. Methods: Subjects ( $n=32$ total) received intranasally administered normal saline or THAM followed by a wash out period prior to receiving the other treatment. Nasal bacterial cultures were obtained prior to and after each treatment period. Results: At baseline, nasal swab bacterial counts were similar between non$\mathrm{CF}$ and $\mathrm{CF}$ subjects, but CF subjects had reduced microbial diversity. Both nasal saline and THAM were well-tolerated. In non-CF subjects, nasal airway alkalinization decreased both the total bacterial density and the gram-positive bacterial species recovered. In both non-CF and CF subjects, THAM decreased the amount of $C$. accolens detected, but increased the amount of $C$. pseudodiphtheriticum recovered on nasal swabs. A reduction in S. aureus nasal colonization was also found in subjects who grew C. pseudodiphtheriticum. Conclusions: This study shows that aerosolized THAM is safe and well-tolerated and that nasal airway alkalinization alters the composition of mucosal bacterial communities. 


\section{INTRODUCTION}

In the $\mathrm{CF}$ airways, loss of $\mathrm{Cl}^{-}$and $\mathrm{HCO}_{3}{ }^{-}$secretion, by the cystic transmembrane conductance regulator (CFTR), causes multiple host defense defects against inhaled and/or aspirated bacteria (1). This leads to recurrent and chronic airway infections and inflammation. While antibiotic use and CFTR modulator therapy have markedly improved outcomes in CF, CF remains a lifeshortening disease and available data suggest that chronic airway infections persist even after treatment with highly effective CFTR modulator therapy (1-5).

The airways are lined with a thin layer of liquid termed the airway surface liquid (ASL), whose composition and volume are tightly regulated (6). The ASL is the first line of defense for the respiratory tract and contains antimicrobial factors, which are important for bacterial killing, and mucus, which plays an important role in mucociliary transport (MCT) $(6,7)$. Newborn CF pigs manifest at least two host defense defects, including impaired antimicrobial factor-mediated bacterial killing and defective mucociliary transport (8-14). Both defects are related to loss of CFTR-mediated $\mathrm{HCO}_{3}{ }^{-}$secretion which leads to a more acidic ASL pH in newborn CF pigs, CF rats, and infants with $\mathrm{CF}$ (15-17). In primary cultures of pig and human CF airway epithelia, similar findings are present (18-21). However, with disease progression the effects of CFTR loss on ASL pH is less clear $(16,22,23)$.

One approach to restoring airway host defenses in $\mathrm{CF}$ would be to raise the ASL $\mathrm{pH}$. In the newborn CF pig airway, airway alkalinization with aerosolized sodium bicarbonate $\left(\mathrm{NaHCO}_{3}\right)$ restored bacterial killing, suggesting that airway alkalinization might be a therapeutic approach in $\mathrm{CF}$ (15). However, this response was transient and ASL pH returned to normal levels within 
30 minutes (24). Aerosolized tromethamine (THAM or tris[hydroxymethyl]aminomethane acetate), another alkalinizing agent, also raised the ASL pH but its effects were much longer lasting than $\mathrm{NaHCO}_{3}$ and persisted for at least 2 hours (24). THAM is an FDA-approved buffer which has been used intravenously for metabolic acidosis in the critical care setting and as an excipient in a number of medications, including inhaled prostacyclin and nasal ketorolac (25, 26). Therefore, aerosolized THAM could represent a novel therapeutic for CF-related airway disease.

While we know that THAM raises ASL pH, we do not know whether ASL alkalinization will alter bacterial density, how much of bacterial killing in vivo is $\mathrm{pH}$-dependent, whether raising $\mathrm{pH}$ might have negative consequences, or how communities of bacteria will respond to alkalinization. This pilot study is the next key step and we tested the hypothesis that nasally administered THAM would alter the nasal bacterial composition in adult subjects, with and without $\mathrm{CF}$. We chose to focus on the upper airways (nose) because aerosolized delivery to this region is straightforward, has minimal risks, microbiological sampling of the nasal airways is relatively easy, and the biology of the upper and lower airways is similar $(27,28)$. 


\section{RESULTS}

\section{Baseline subject characteristics}

A total of 32 subjects were enrolled in the study (16 non-CF and 16 CF subjects) (Table 1).

Age, sex, and race were similar between the two groups. Eighty-one percent of CF subjects had at least one $\triangle F 508-C F T R$ allele present. Prior to study enrollment, the average $\mathrm{FEV}_{1} \%$ predicted was $73 \%$ in CF participants. No subjects were lost to follow-up. Treatment compliance was excellent with non-CF and CF subjects completing $97 \%$ and $99 \%$ of aerosolized treatments, respectively. Both aerosolized saline and THAM were very well-tolerated. Adverse events were limited with 4 events noted during saline treatment ( 1 cough, 2 shortness of breath, 1 chest tightness) and 2 during THAM treatment (1 sneezing, 1 back pain) (Supplemental Table 1).

In preliminary studies, we found that both total amount and types of bacteria recovered from the nares were stable over time (Supplemental Figure 1A-D). Prior to any treatments, nasal mucosal swabs recovered similar numbers of bacteria from non-CF and CF subjects $(4.03 \pm 0.25$ vs. $3.91 \pm 0.24 \log _{10} \mathrm{CFU} / \mathrm{ml}, \mathrm{P}=0.731$ ) (Supplemental Figure 2A). In the current study, bacterial diversity, represented by the number of different bacterial species isolated, was reduced in CF compared to non-CF subjects (mean number of different species present: $2.6 \pm 0.3$ vs. 3.9 $\pm 0.5, P=0.023)$ (Supplemental Figure 2B). In both non-CF and CF subjects, the majority of bacteria isolated were gram-positive species (Supplemental Table 2). Gram-negative bacterial species were not frequently isolated from either non-CF or CF subjects, but were more commonly cultured from $\mathrm{CF}$ nasal mucosa with the most common in $\mathrm{CF}$ being $P$. aeruginosa, 
Achromobacter xylosoxidans, and Serratia marcescens. P. aeruginosa was only cultured from the nares of CF subjects.

\section{Nasal airway alkalinization decreases gram-positive bacterial species in non-CF subjects}

Aerosolized THAM reduced the total number of bacteria recovered from the nares of non-CF subjects (Figure 1A), and this effect was primarily due to a decrease in gram-positive bacteria $\left(3.96 \pm 0.98\right.$ vs $\left.3.18 \pm 1.11 \log _{10} \mathrm{CFU} / \mathrm{ml}, \mathrm{P}=0.005\right)$ (Figures 1B and 1C). Nasal saline aerosolization had no effect on the counts of total and gram-positive bacteria recovered from the nares of non-CF subjects (Figure 1A and 1B). Unexpectedly, nasal saline decreased the total number of gram-negative bacteria $\left(0.86 \pm 1.20\right.$ vs. $\left.0.15 \pm 0.60 \log _{10} \mathrm{CFU} / \mathrm{ml}, \mathrm{P}=0.020\right)$ (Figure 1C), although most participants had no gram-negative or relatively low levels of these organisms.

In CF subjects, aerosolized THAM or saline had no effect on total bacterial counts or the total number of gram-positive or gram-negative bacteria recovered (Figures 1D-F). Prior to THAM treatment, $P$. aeruginosa was recovered from the nares of 4 people with CF. Following THAM treatment, $P$. aeruginosa was only recovered from 1 of these 4 subjects and in this remaining subject THAM decreased the amount of $P$. aeruginosa (4.18 vs. $\left.2.70 \log _{10} \mathrm{CFU} / \mathrm{ml}\right)$. Saline had no significant effect on $P$. aeruginosa recovery.

In non-CF subjects, the four most common gram-positive organisms detected on nasal swabs at baseline were S. epidermidis, S. aureus, C. accolens, and C. pseudodiphtheriticum. Aerosolized THAM, but not saline, treatment decreased the amount of S. epidermidis (3.11 \pm 1.06 vs. $2.74 \pm$ 
$\left.0.98 \log _{10} \mathrm{CFU} / \mathrm{ml}, \mathrm{P}=0.031\right), S$. aureus $\left(1.82 \pm 2.18\right.$ vs. $\left.1.12 \pm 1.75 \log _{10} \mathrm{CFU}, \mathrm{P}=0.089\right)$, and C. accolens $\left(1.03 \pm 1.93\right.$ vs. $\left.0.26 \pm 0.74 \log _{10} \mathrm{CFU}, \mathrm{P}=0.183\right)$ cultured from nasal swabs

(Figures 2A-C). In contrast, we cultured higher amounts of $C$. pseudodiphtheriticum following THAM treatment $\left(0.51 \pm 1.40\right.$ vs. $1.05 \pm 1.72 \log _{10} \mathrm{CFU} / \mathrm{ml}, \mathrm{P}=0.066$ (Figure 2D).

Since the number of subjects in each group with C. accolens or C. pseudodiphtheriticum was relatively low, we combined the values from non-CF and $\mathrm{CF}$ subjects and reanalyzed the data. A similar pattern was observed with THAM treatment decreasing the amount of C. accolens, but increasing the amount of $C$. pseudodiphtheriticum cultured from nasal swabs (Figures 3A and 3B). We also found that following THAM treatment, C. accolens was less frequently detected on nasal swabs ( $9 \%$ vs. $31 \%$ for saline treatment, $\mathrm{P}=0.03)$ while there was a trend towards increased detection of $C$. pseudodiphtheriticum ( $9 \%$ vs. $19 \%$ for THAM treatment, $\mathrm{P}=0.28$ ) (Table 2). Finally, the presence of C. pseudodiphtheriticum, but not C. accolens, in both non-CF and CF subjects, was associated with a significantly lower rate of $S$. aureus detection on nasal swab cultures (Figure 3C). 


\section{DISCUSSION}

In this study investigating the effects of nasal alkalinization, we found that THAM was welltolerated and altered the types of bacteria cultured from the nasal mucosa of both non-CF and $\mathrm{CF}$ subjects. We had four main conclusions. First, at baseline, non-CF and CF subjects had similar total numbers of bacteria detected on nasal swabs, but there was less microbial diversity in CF. Second, airway alkalinization with THAM preferentially reduced the total number of grampositive bacteria recovered in non-CF subjects, but had less of an effect in CF. Third, following airway alkalinization, nasal swab cultures were less frequently positive for C. accolens. Finally, the presence $C$. pseudodiphtheriticum was associated with much less frequent recovery of $S$. aureus.

We found that THAM's effects were most significant for gram-positive species. This is likely because, in part, gram-negative species are uncommonly present in the upper airways, with less than $10 \%$ of healthy individuals nasally colonized with gram-negative bacteria (31). We also observed low rates of gram-negative bacteria in the nares of non-CF subjects. Although this was only a small pilot study, we did observe that THAM treatment decreased $P$. aeruginosa detection from the nares of $\mathrm{CF}$ subjects. Whether this effect is reproducible in a larger patient population or in the lower airways is not known, but would be an important endpoint for future studies of airway alkalinization of individuals with CF colonized with P. aeruginosa.

An interesting finding was that airway alkalinization altered the types and amounts of bacteria recovered from the nares of non-CF and CF subjects. Specifically, following THAM treatment, decreased amounts of $C$. accolens were cultured, while increased amounts of $C$. 
pseudodiphtheriticum were present on nasal swab cultures. While we did not investigate the underlying mechanism several potential explanations exist. First, THAM might directly affect the growth of certain bacterial species. THAM could inhibit the growth of $C$. accolens, but promote the growth of $C$. pseudodiphtheriticum. Second, it is possible that airway alkalinization alters the nasal mucosa's innate defenses. The bacterial killing activity of many antimicrobial factors present on the airway surface is affected by $\mathrm{pH}$ (32). Airway alkalinization could enhance or diminish antimicrobial factor killing of different bacterial species and alter the bacterial community composition. Finally, alkalinization and environmental changes might select for certain bacterial species which then shift the remaining microbial community. $C$. accolens has been shown to have a symbiotic effect when cultured with $S$. aureus, while $C$. pseudodiptheriticum negatively affects the growth of $S$. aureus $(33,34)$. Interestingly, an earlier study found that nasal inoculation with $C$. pseudodiphtheriticum significantly decreased $S$. aureus nasal carriage (35). Thus, THAM might be selecting for $C$. pseudodiphtheriticum which then reduces the amount of Staphylococcus and C. accolens. This might represent an example of how changing the local host enviroment favors the colonization of different bacterial species.

Although we did not observe that nasal THAM alkalinization decreased the frequency of $S$. aureus detection, there was a reduction in the amount of $S$. aureus cultured from nasal swabs. It is possible that with a more prolonged duration of akalinization, THAM might represent a novel therapeutic strategy for $S$. aureus decolonization. Nasal THAM administration might be a simple, cost-effective, and efficacious approach for nasal $S$. aureus decolonization, but will require future studies designed to test its effectiveness. The mechanism underlying THAM's effects are likely due to increased activity of antimicrobial-factors. Since resistance to multiple 
innate factors is difficult to develop, this approach would be less likely to cause bacterial resistance.

This study has both advantages and limitations. Advantages include: a) We studied both non-CF and CF human subjects. b) A cross-over study design was utilized allowing for comparisons to be made on the same subject. c) An FDA-approved formulation of THAM was used. Limitations include: a) This was a pilot study, at a single-center, with a limited number of subjects. b) We only studied the upper (nasal) airways. However, this allowed us to easily administer treatments and sample the airways. c) The study duration was short. We do not know the long-term effects of airway alkalinization on airway bacterial colonization. d) Bacterial recovery with nasal swabs can be variable, but we standardized the approach based upon currently accepted techniques. e) We did not measure the effects of THAM on nasal $\mathrm{pH}$. However, in an earlier study we found that the effect lasted close to 6 hours (24). Thus, we likely had prolonged airway alkalinization by administering the treatment three times per day.

In conclusion, nasal THAM administration was safe and well-tolerated in both non-CF and CF subjects. THAM treatment decreased the number of gram-positive bacteria cultured from the nasal mucosa of non-CF subjects, but had less of an effect in $\mathrm{CF}$. In both non-CF and $\mathrm{CF}$ subjects, alkalinization was associated with reduced C. accolens detection and a trend towards greater rates of $C$. pseudodiphtheriticum nasal carriage. Future studies will be required to further understand the mechnaisms underlying the changes in the bacterial communities. Finally, airway alkalinization with THAM might represent a potential therapeutic approach in early CF. 


\section{METHODS}

Subjects. All subjects were recruited and enrolled at the University of Iowa Hospital. We enrolled people with and without CF age 16 or greater, who were able to provide written consent. A CF diagnosis required one or more features consistent with $\mathrm{CF}$ and one or more of the following criteria: a) sweat chloride $\geq 60 \mathrm{mEq} / \mathrm{L}$; b) two mutations in CFTR; or c) an abnormal nasal potential difference (29). Inclusion criteria for $\mathrm{CF}$ subjects included resting $\mathrm{O}_{2}$ saturation $>$ $90 \%$ on room air and clinically stable for at least 14 days prior to Day 1 of the study. CF subjects were recruited from the CF clinic. Exclusion criteria were pregnancy, tobacco use, recreational drug use, use of any investigational study drug within 28 days, or clinical findings consistent with a CF pulmonary exacerbation or flare up of seasonal allergic rhinitis. Baseline pulmonary function testing (PFT) was available for only the CF subjects.

Study approval. The University of Iowa IRB as well as the FDA approved the studies. A written informed consent was received from participants prior to inclusion in the study. The clinical trial registration number for this study is NCT03078088.

Study Design and Protocol. This pilot study was a prospective, randomized, cross-over design. Subjects were randomized to receive either normal saline $(0.9 \%$, Baxter Health Care, Mundelein, IL) $(250 \mu \mathrm{l} /$ dose $)$ or THAM (3.6\%, pH 8.6, Pfizer) $(250 \mu \mathrm{l} /$ dose $) 3$ times a day for 4 days. After a 10 - 14 day wash out period, subjects then received the other treatment for 4 days. An Accuspray syringe (Becton Dickinson, Franklin Lakes, NJ) was used to aerosolize the solutions onto the nasal epithelium, as previously described (30). Subjects received prefilled syringes from Nucara Pharmacy (Waterloo, IA). These treatments were self-administered by the study 
subjects. Bacterial cultures of the anterior nares were obtained before and after each round of treatment.

Nasal Swab Sampling and Microbiology. Nasal bacteria were recovered by gently inserting a flexible minitip flocked swab (BD ESwab, cat\# 220532) into the right nare $6 \mathrm{~cm}$ and completely rotating the swab three times. The swab was carefully removed, placed in $1 \mathrm{ml}$ of media, and vortexed for 20 seconds. The same procedure was performed in the left nare with a different swab. Using standard microbiological techniques, the media was plated for bacterial quantification and identification via MALDI-TOF mass spectrometry. Data from the right and left nares were combined for each subject at the different time points.

Statistical Analyses. Data are presented as points from individual donors with mean $\pm \mathrm{SEM}$ indicated by bars. For statistical analysis, we used a two sample t-test, Mann-Whitney test, Wilcoxon signed-rank test, or a 1-way ANOVA. Bacterial counts were log-transformed. Prior to $\log$ transformation, a value of 1 was added to all CFU data. Differences were considered statistically significant at $\mathrm{P}<0.05$. 


\section{TRANSPARENCY DECLARATION}

Conflict of Interest: Drs. Zabner and Stoltz have a patent application pending related to this work.

Funding: This research was supported, in part, by the NIH (HL136813, HL091842, and HL007638), and the Cystic Fibrosis Foundation (Iowa Cystic Fibrosis Foundation Research Development Program). This study was also supported by the National Center For Advancing Translational Sciences of the NIH under award number UL1TR002537.

Acknowledgements: The authors thank the people with CF for their participation. We thank Linda Boyken, Nick Gansemer, Mal Stroik, and Anne Vincent for excellent assistance. We thank the members of the data and safety monitoring board, Drs. Doug Hornick and Anthony Fischer, for their valuable service to this study.

Access to Data: The data are available from Drs. Zabner and Stoltz.

Contributions: ZMH, LD, PKS, JZ, DAS conception and design of research; ZMH, JLL performed experiments and data acquisition; ZMH, JZ, DAS analyzed data; ZMH, LD, PKS, JZ, DAS interpreted results of experiments; ZMH, DAS, JZ prepared figures; ZMH, JZ, DAS drafted manuscript; ZMH, JLL, LD, PKS, JZ, DAS edited, reviewed, and approved final version of manuscript. 


\section{REFERENCES}

1. Stoltz DA, Meyerholz DK, Welsh MJ. Origins of cystic fibrosis lung disease. $N$ Engl J Med 372:351-362 (2015).

2. Joshi D, Ehrhardt A, Hong JS, Sorscher EJ. Cystic fibrosis precision therapeutics: Emerging considerations. Pediatr Pulmonol 54 Suppl 3:S13-S17 (2019).

3. Middleton PG, Mall MA, Drevinek P, Lands LC, McKone EF, Polineni D, et al. Elexacaftor-Tezacaftor-Ivacaftor for Cystic Fibrosis with a Single Phe508del Allele. $N$ Engl J Med 381:1809-1819 (2019).

4. Saiman L. Improving outcomes of infections in cystic fibrosis in the era of CFTR modulator therapy. Pediatr Pulmonol 54 Suppl 3:S18-S26 (2019).

5. Bell SC, Mall MA, Gutierrez H, Macek M, Madge S, Davies JC, et al. 2The future of cystic fibrosis care: a global perspective. Lancet Respir Med doi:10.1016/S22132600(19)30337-6 (2019).

6. Widdicombe JH, Wine JJ. Airway Gland Structure and Function. Physiol Rev 95:1241319 (2015).

7. Xie Y, Ostedgaard L, Abou Alaiwa MH, Lu L, Fischer AJ, Stoltz DA. 2Mucociliary Transport in Healthy and Cystic Fibrosis Pig Airways. Ann Am Thorac Soc 15:S171S176 (2018).

8. Stoltz DA, Rokhlina T, Ernst S, Pezzulo AA, Ostedgaard LS, Karp PH, et al. Intestinal CFTR expression alleviates meconium ileus in cystic fibrosis pigs. J Clin Invest 123:2685-2693 (2013).

9. Hoegger MJ, Fischer AJ, McMenimen JD, Ostedgaard LS, Tucker AJ, Awadalla MA, et al. Impaired mucus detachment disrupts mucociliary transport in a piglet model of cystic fibrosis. Science 345:818-22 (2014).

10. Tang XX, Ostedgaard LS, Hoegger MJ, Moninger TO, Karp PH, McMenimen JD, et al. Acidic $\mathrm{pH}$ increases airway surface liquid viscosity in cystic fibrosis. $J$ Clin Invest 126:879-91 (2016).

11. Rogers CS, Abraham WM, Brogden KA, Engelhardt JF, Fisher JT, McCray PB, Jr., et al. 2008. The porcine lung as a potential model for cystic fibrosis. Am J Physiol Lung Cell Mol Physiol 295:L240-63 (2008).

12. Rogers CS, Stoltz DA, Meyerholz DK, Ostedgaard LS, Rokhlina T, Taft PJ, et al. Disruption of the CFTR gene produces a model of cystic fibrosis in newborn pigs. Science 321:1837-1841 (2008). 
13. Stoltz DA, Meyerholz DK, Pezzulo AA, Ramachandran S, Rogan MP, Davis GJ, et al. Cystic fibrosis pigs develop lung disease and exhibit defective bacterial eradication at birth. Sci Transl Med 2:29ra31 (2010).

14. Ostedgaard LS, Meyerholz DK, Chen J-H, Pezzulo AA, Karp PH, Rokhlina T, et al. The $\triangle$ F508 mutation causes CFTR misprocessing and cystic fibrosis-like disease in pigs. Sci Transl Med 3:74ra24 (2011).

15. Pezzulo AA, Tang XX, Hoegger MJ, Alaiwa MH, Ramachandran S, Moninger TO, et al. Reduced airway surface $\mathrm{pH}$ impairs bacterial killing in the porcine cystic fibrosis lung. Nature 487:109-113(2012).

16. Abou Alaiwa MH, Beer AM, Pezzulo AA, Launspach JL, Horan RA, Stoltz DA, et al. Neonates with cystic fibrosis have a reduced nasal liquid $\mathrm{pH}$; A small pilot study. J Cyst Fibros 13:373-377 (2014).

17. Birket SE, Davis JM, Fernandez CM, Tuggle KL, Oden AM, Chu KK, et al. Development of an airway mucus defect in the cystic fibrosis rat. JCI Insight 3:e97199 (2018).

18. Shah VS, Meyerholz DK, Tang XX, Reznikov L, Abou Alaiwa M, Ernst SE, et al. Airway acidification initiates host defense abnormalities in cystic fibrosis mice. Science 351:503-507 (2016).

19. Coakley RD, Grubb BR, Paradiso AM, Gatzy JT, Johnson LG, Kreda SM, et al. Abnormal surface liquid $\mathrm{pH}$ regulation by cultured cystic fibrosis bronchial epithelium. Proc Natl Acad Sci U S A 100:16083-16088 (2003).

20. Garland AL, Walton WG, Coakley RD, Tan CD, Gilmore RC, Hobbs CA, et al. Molecular basis for $\mathrm{pH}$-dependent mucosal dehydration in cystic fibrosis airways. Proc Natl Acad Sci U S A 110:15973-15978 (2013).

21. Simonin J, Bille E, Crambert G, Noel S, Dreano E, Edwards A, et al. Airway surface liquid acidification initiates host defense abnormalities in Cystic Fibrosis. Sci Rep 9:6516 (2019).

22. McShane D, Davies JC, Davies MG, Bush A, Geddes DM, Alton EW. Airway surface $\mathrm{pH}$ in subjects with cystic fibrosis. Eur Respir J 21:37-42 (2003).

23. Schultz A, Puvvadi R, Borisov SM, Shaw NC, Klimant I, Berry LJ, et al. Airway surface liquid $\mathrm{pH}$ is not acidic in children with cystic fibrosis. Nat Commun 8:1409 (2017).

24. Abou Alaiwa MH, Launspach JL, Sheets KA, Rivera JA, Gansemer ND, Taft PJ, et al. Repurposing Tromethamine as inhaled therapy to treat CF airway disease. JCI Insight 1:e87535 (2016). 
25. US AP. 2009. Ventavis ${ }^{\circledR}$ (iloprost) inhalation solution. Prescribing information.

26. Quadir M, Zia H, Needham TE. Development and evaluation of nasal formulations of ketorolac. Drug Deliv 7:223-229 (2000).

27. Krouse JH. The unified airway--conceptual framework. Otolaryngol Clin North Am 41:257-66, v (2008).

28. Vieira Braga FA, Kar G, Berg M, Carpaij OA, Polanski K, Simon LM, et al. A cellular census of human lungs identifies novel cell states in health and in asthma. Nat Med 25:1153-1163 (2019).

29. De Boeck K, Vermeulen F, Dupont L. The diagnosis of cystic fibrosis. Presse Med 46:e97-e108 (2017).

30. Zabner J, Seiler MP, Launspach JL, Karp PH, Kearney WR, Look DC, et al. The osmolyte xylitol reduces the salt concentration of airway surface liquid and may enhance bacterial killing. Proc Natl Acad Sci U S A 97:11614-11619 (2000).

31. Korona-Glowniak I, Grywalska E, Chudzik B, Bojarska-Junak A, Malm A, Rolinski J. Upper respiratory tract colonization by gram-negative rods in patients with chronic lymphocytic leukemia: analysis of risk factors. Scientific World Journal 2012:617218 (2012).

32. Abou Alaiwa MH, Reznikov LR, Gansemer ND, Sheets KA, Horswill AR, Stoltz DA, et al. $\mathrm{pH}$ modulates the activity and synergism of the airway surface liquid antimicrobials beta-defensin-3 and LL-37. Proc Natl Acad Sci U S A 111:18703-18708 (2014).

33. Yan M, Pamp SJ, Fukuyama J, Hwang PH, Cho DY, Holmes S, et al. Nasal microenvironments and interspecific interactions influence nasal microbiota complexity and S. aureus carriage. Cell Host Microbe 14:631-40 (2013).

34. Hardy BL, Dickey SW, Plaut RD, Riggins DP, Stibitz S, Otto M, et al. Corynebacterium pseudodiphtheriticum Exploits Staphylococcus aureus Virulence Components in a Novel Polymicrobial Defense Strategy. MBio 10:e)2491-18 (2019).

35. Kiryukhina NV, Melnikov VG, Suvorov AV, Morozova YA, Ilyin VK. Use of Corynebacterium pseudodiphtheriticum for elimination of Staphylococcus aureus from the nasal cavity in volunteers exposed to abnormal microclimate and altered gaseous environment. Probiotics Antimicrob Proteins 5:233-8 (2013). 


\section{FIGURE LEGENDS}

\section{Figure 1. The Effects of Airway Alkalinization on Nasal Bacteria in Non-CF and CF}

Subjects. (A) Total bacteria, (B) Gram-positive bacteria, and (C) Gram-negative bacteria cultured from nasal swabs before and after nasal aerosolization with THAM (red symbols) or saline (blue symbols) in non-CF subjects. (D) Total bacteria, (E) Gram-positive bacteria, and (F) Gram-negative bacteria cultured from nasal swabs before and after nasal aerosolization with THAM (red symbols) or saline (blue symbols) in CF subjects. Each data point indicates nasal swab data from a different subject. Connected symbols represent individual subjects before and after treatment. $\mathrm{n}=16$ subjects for non-CF and 16 subjects for CF. Numbers in parenthenses represent the number of subjects with a bacterial count of " 0 " and have superimposed data points. Horizontal bars represent mean \pm SEM. * denotes $\mathrm{P}<0.05$.

\section{Figure 2. The Effects of Airway Alkalinization on the Most Common Gram-Positive Nasal}

Bacterial Species in Non-CF Subjects. Nasal bacterial counts for (A) S. epidermidis, (B) $S$. aureus, (C) C. accolens, and (D) C. pseudodiphtheriticum. Bacteria recovered before and after nasal aerosolization with THAM (red symbols) or saline (blue symbols) in non-CF subjects. Each data point indicates nasal swab data from a different subject. Connected symbols represent individual subjects before and after treatment. $n=16$ subjects. Numbers in parenthenses represent the number of subjects with a bacterial count of " 0 " and have superimposed data points. Horizontal bars represent mean \pm SEM. * denotes $\mathrm{P}<0.05$. 
Figure 3. THAM's Effects on C. accolens, $C$. pseudodiphtheriticum, and S. aureus in non-CF

and CF Subjects. Nasal bacterial counts for (A) C. accolens and (B) C. pseudodiphtheriticum, in non-CF and CF subjects. Bacteria recovered before and after nasal aerosolization with THAM (red symbols) or saline (blue symbols) in non-CF and CF subjects. Each data point indicates nasal swab data from a different subject. Connected symbols represent individual subjects before and after treatment. $\mathrm{n}=32$ subjects. Numbers in parenthenses represent the number of subjects with a bacterial count of " 0 " and have superimposed data points. Horizontal bars represent mean \pm SEM. * denotes $\mathrm{P}<0.05$. (C) Percentage of nasal bacterial swab samples positive for $S$. aureus in the absence and presence of C. accolens- or C. pseudodiphtheriticum positive samples. * denotes $\mathrm{P}<0.05$. 
Fig. 1 It is made available under a CC-BY 4.0 International license .
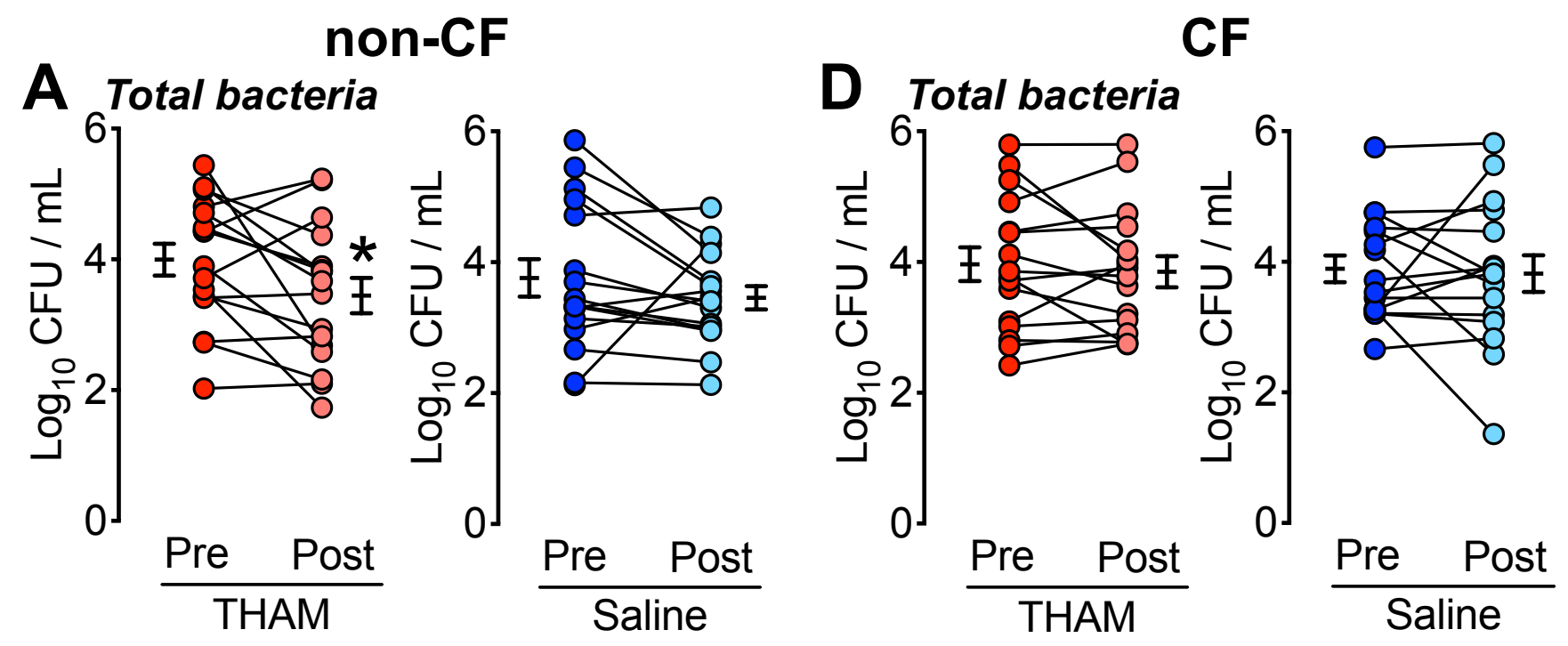

B Gram (+) species
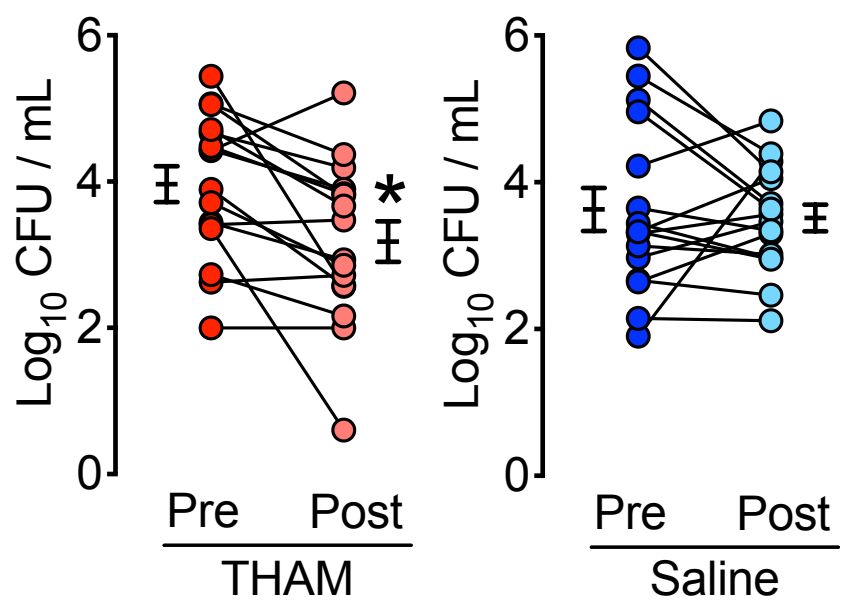

E Gram (+) species

C Gram (-) species
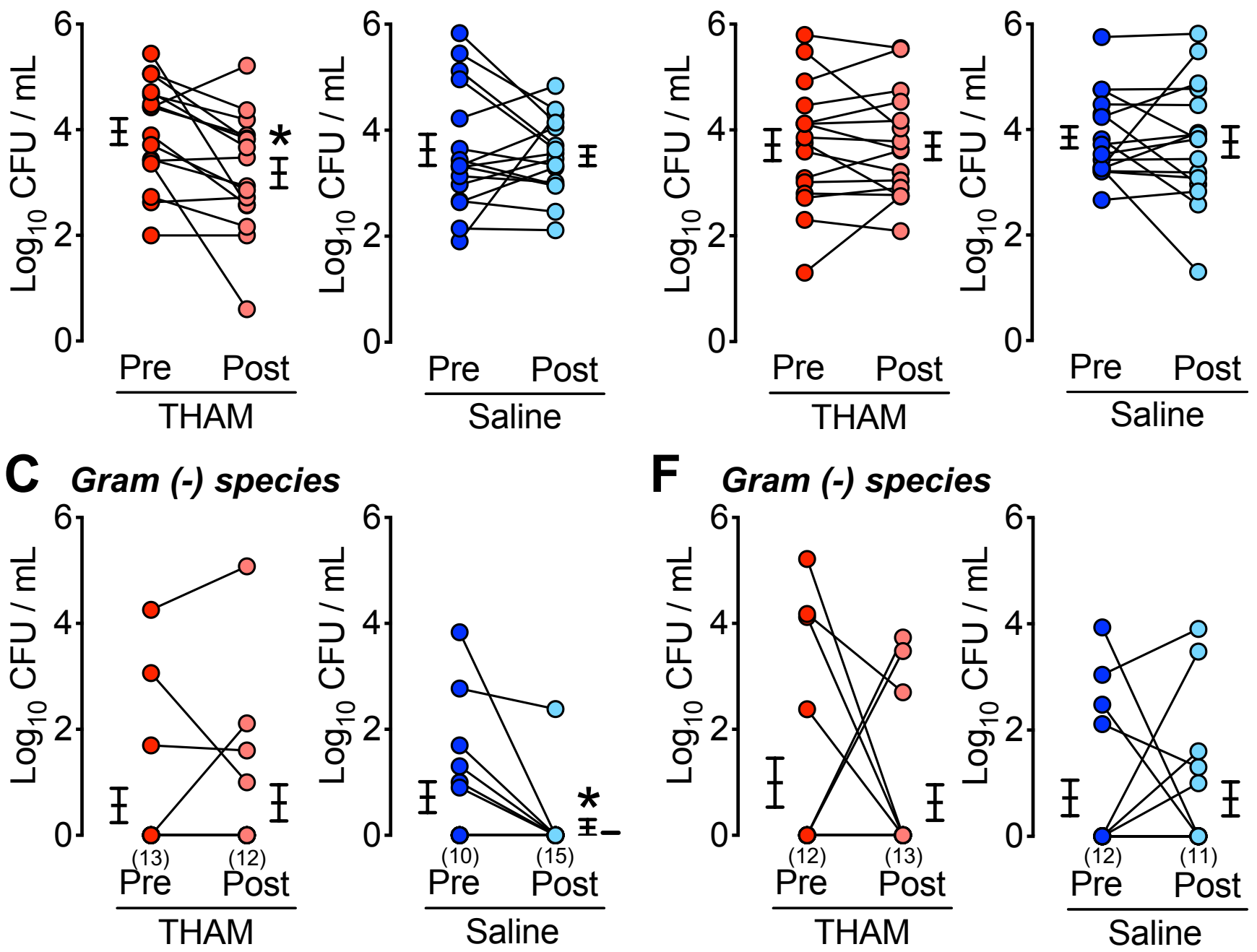

F Gram (-) species

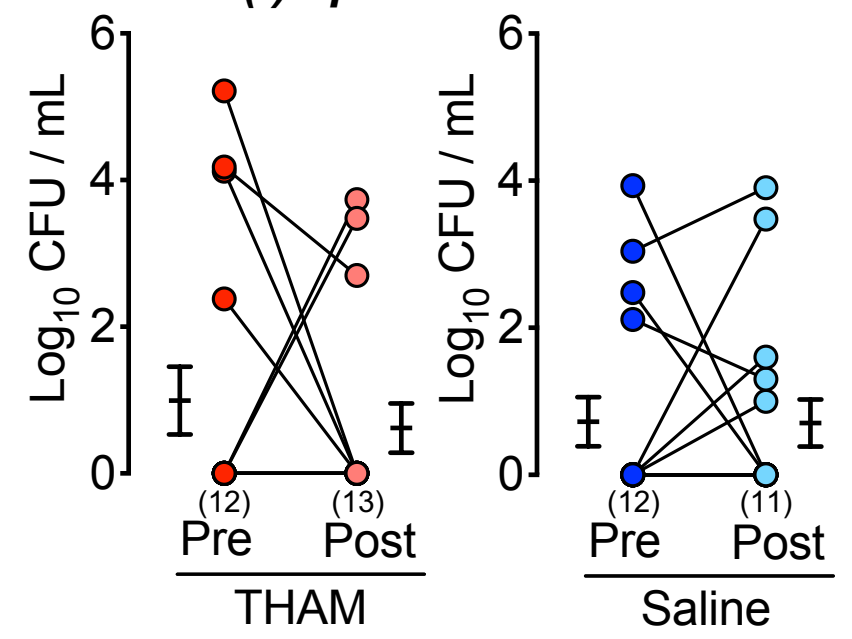


Fig. 2
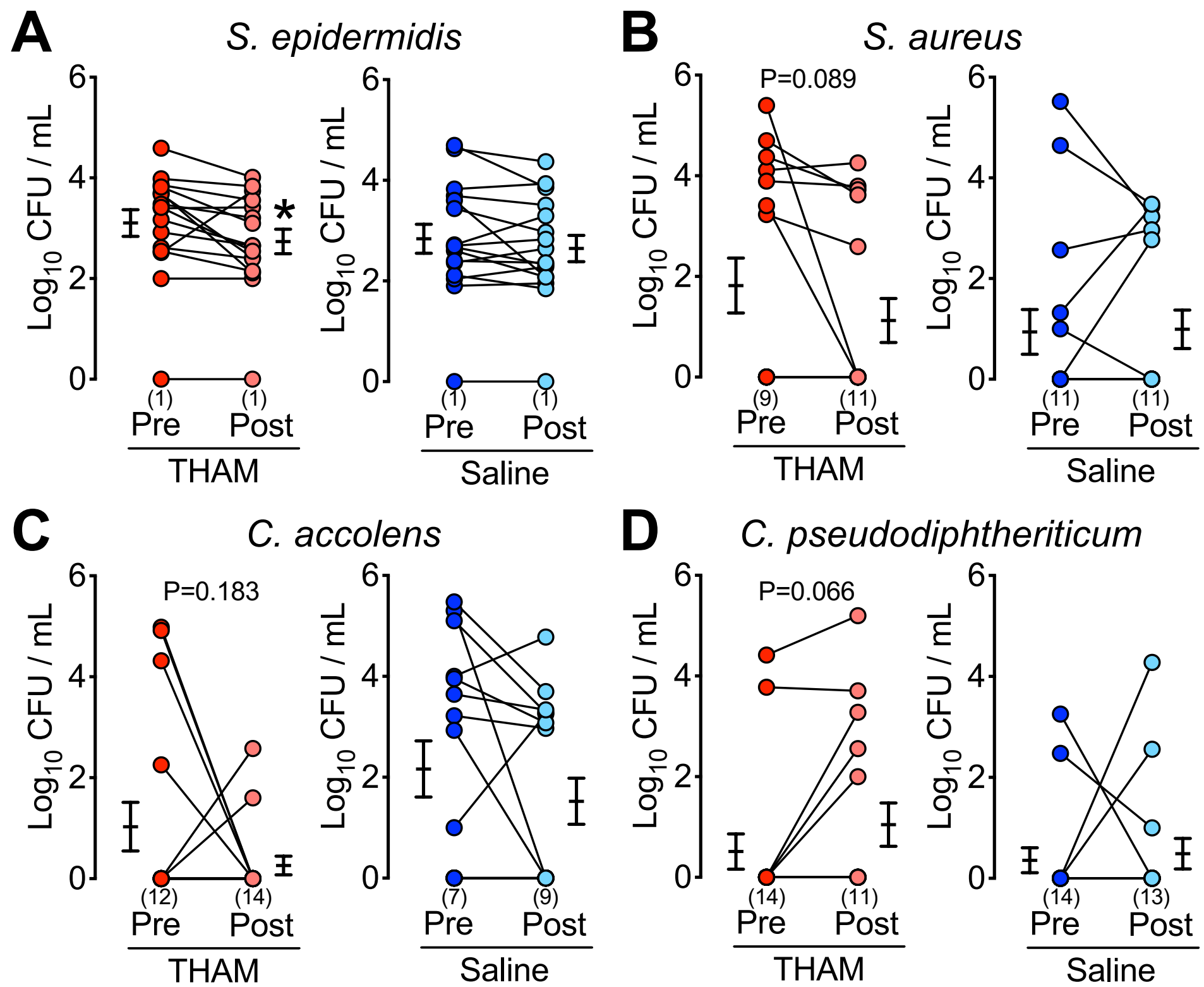

C. pseudodiphtheriticum
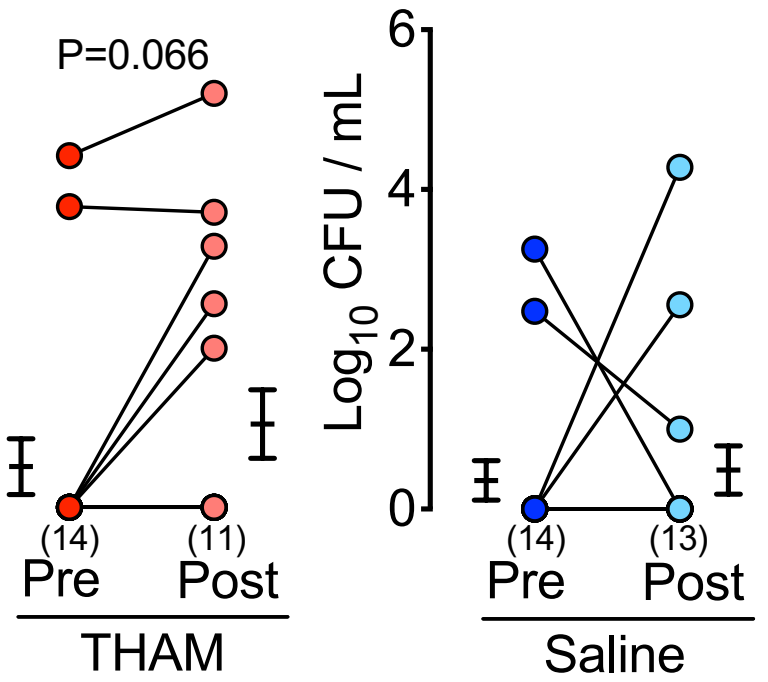
medRxiv preprint doi: https://doi.org/10.1101/2021.02.14.21251657; this version posted February 16, 2021. The copyright holder for this preprint (which was not certified by peer review) is the author/funder, who has granted medRxiv a license to display the preprint in perpetuity.

It is made available under a CC-BY 4.0 International license .

Fig. 3

A

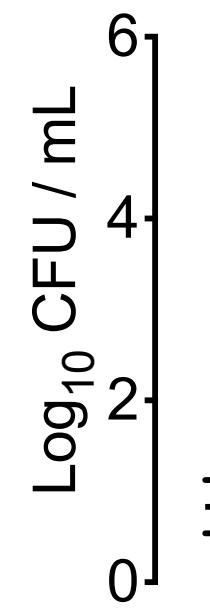

C. accolens

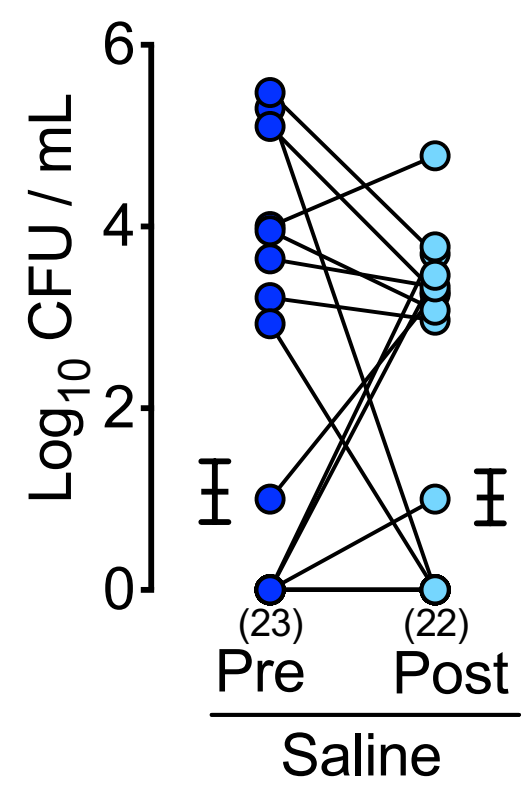

B

C. pseudodiphtheriticum
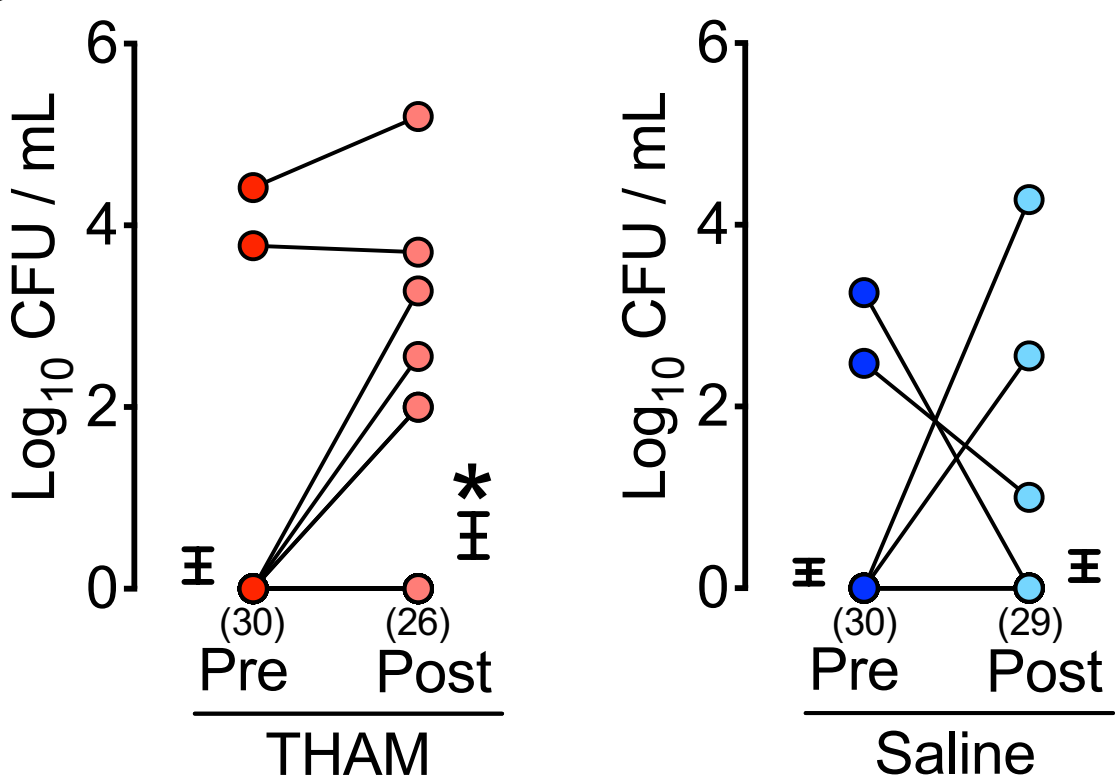

C
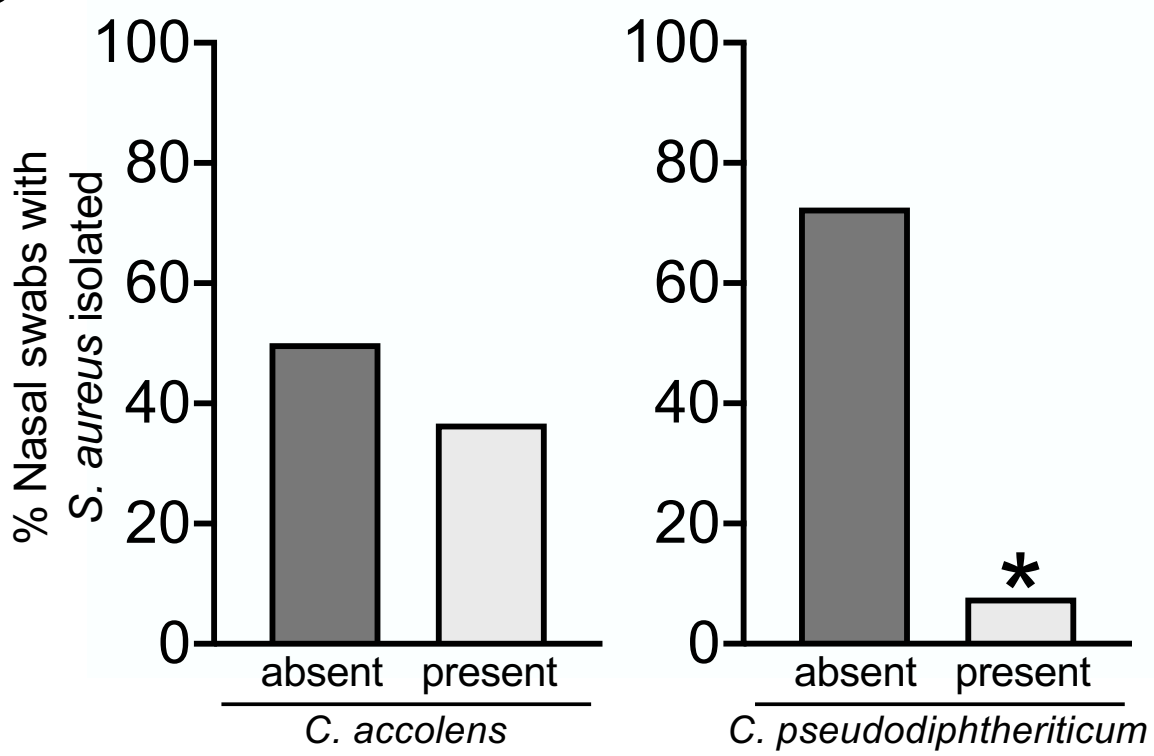
medRxiv preprint doi: https://doi.org/10.1101/2021.02.14.21251657; this version posted February 16, 2021. The copyright holder for this preprint (which was not certified by peer review) is the author/funder, who has granted medRxiv a license to display the preprint in perpetuity.

Table 1

It is made available under a CC-BY 4.0 International license.

\section{Subject Demographics}

\begin{tabular}{|c|c|c|}
\hline & non-CF & CF \\
\hline Number of subjects & 16 & 16 \\
\hline Age (vrs) & 33 & 29 \\
\hline Male/female & $5 / 11$ & 9/7 \\
\hline Caucasian/white & $15(94 \%)$ & $16(100 \%)$ \\
\hline$\Delta \mathrm{F} 508$ heterozygotes & $\mathrm{N} / \mathrm{A}$ & $8(50 \%)$ \\
\hline$\Delta \mathrm{F} 508$ homozygotes & N/A & $5(31 \%)$ \\
\hline $\mathrm{FEV}_{1}(\%$ predicted $)$ & N/A & $73 \%$ \\
\hline
\end{tabular}


medRxiv preprint doi: https://doi.org/10.1101/2021.02.14.21251657; this version posted February 16, 2021. The copyright holder for this preprint (which was not certified by peer review) is the author/funder, who has granted medRxiv a license to display the preprint in perpetuity.

Table 2

It is made available under a CC-BY 4.0 International license.

Nasal Swab Detection of C. accolens and C. pseudodiphtheriticum

\begin{tabular}{|l|c|c|c|c|c|c|}
\hline & \multicolumn{3}{|c|}{ C. accolens } & \multicolumn{3}{c|}{ C. pseudodiphtheriticum } \\
\cline { 2 - 7 } & Negative & Positive & P-value & Negative & Positive & $P$-value \\
\hline Post-Saline & $69 \%$ & $31 \%$ & 0.03 & $91 \%$ & $9 \%$ & 0.28 \\
\hline & & & & & & \\
\hline Post-THAM & $91 \%$ & $9 \%$ & & $81 \%$ & $19 \%$ & \\
\hline
\end{tabular}

